\title{
Danmark ikke Tysklands drømmeformandsland
}

\section{Peter Wivel}

\section{Tysklands EU-dagsorden for 2012's første halvår byder på udfordringer, som det vil kræeve stor dansk fingerspidsfornemmelse at håndtere. Danmark er på tværs af Tyskland om meget, men de står sammen om energipolitik}

Første halvår af 2012 bliver en skæbnetime for Europa. I 17 eurolande skal den fælles mønt sikres, hvis ikke ligefrem reddes. Euroens skæbne har den allerstørste betydning også for de resterende ti lande, herunder Danmark.

Den schweiziske storbank UBS's analyseafdeling konkluderede i september, at "de økonomiske omkostninger ved at sige farvel til euroen er høje og ekstremt farlige. De politiske omkostninger ved at sige farvel til euroen, er for store til, at man overhovedet kan sætte konkrete beløb på dem”.

Dommedagsprofeter, især i Storbritannien, har ikke desto mindre ikke blot afskrevet Grækenland som EU-medlem, men hele EU-samarbejdet. Andre, fx den amerikanske øko- nom Barry Eichengreen, Berkeley i Californien, siger, at det er lige så usandsynligt, at et land udtræeder af eurozonen, som at en meteorit rammer Eurotårnet i Frankfurt.

Vi får se, hvem der får ret. Men inden for så vide rammer skulle der være et stort politisk råderum. Spørgsmålet er dog, om lige præcis Danmark er den drømmepartner, Tyskland ønsker sig i kampen for at sikre, at landet ikke forgæves har sat flere hundrede milliarder euro på højkant.

Hvorom alting er: Hvis man ikke kan få den, man vil have, må man tage den, man kan få. For slaget skal slås nu. Om endnu et halvt år er det for sent.

Problemerne er velkendte: Danmark er ikke med i eurozonen. Det 
er svært at forestille sig statsminister Helle Thorning-Schmidt som den, der frelser en valuta, vi ikke vil handle med i Danmark. I hvert fald, hvis man hedder Angela Merkel og er kansler i Tyskland.

Ikke desto mindre byder hovedoverskrifterne på den tyske EU-dagsorden for 2012's første to kvartaler på udfordringer, som det vil kræve stor dansk fingerspidsfornemmelse at håndtere.

I denne artikel skal vi beskæftige os med fire højtprioriterede områder. De tre træder direkte på ømme danske tæer, mens det fjerde bestyrker en dansk undtagelsesposition. 1 Møntunionen skal forvandles til en stabilitetsunion.

2 Lissabon-traktaten skal reguleres, måske ligefrem ændres.

3 Det europæiske forsvarssamarbejde skal have sit eget hovedkvarter og 4 Det europæiske atomsamarbejde skal nedtrappes

Kun hvad det sidste punkt angår, gør Danmark, der aldrig har haft atomkraft, helt klart fælles sag med Tyskland, der afvikler sin.

I det danske oplæg til formandskab er flere af disse dagsordenspunkter næunt eller antydet. Vi er klar over udfordringen, selv om det bliver en kamp op ad bakke.

\section{Stabilitetsunionen}

Lad os se på de tyske prioriteringer, som de fremgik af en tale, Angela Merkel holdt i den tyske Forbunds- dag den 26. oktober. Den tyske strategi er tostrenget. Den handler dels om, hvad man kan gøre inden for rammerne af den nuværende Lissabon-traktat, dels om, hvad der må ændres eller tilføjes traktaten for så vidt, det angår de 17 eurolande.

Merkel sagde om det første skridt på vejen mod en 'stabilitetsunion':

"Forbundsregeringen ønsker, at $\varnothing$ konomi- og Valutaunionen bliver en Stabilitetsunion. Derfor må vi ved siden af beherskelsen af den akutte krise naturligvis også drage omsorg for fremtiden på den måde, at euromedlemsstaterne i højere grad overtager flere fælles forpligtelser".

Hun fortsatte: "Vi vil bede rådsformanden om at udarbejde forslag til december om, hvordan vi bedre kan forankre stabilitetskulturen. Her drejer det sig ikke om en omfattende reform af Lissabon-traktaten - så havde man påtaget sig for meget. Det drejer sig heller ikke om, at fællesskabet overtager yderligere dele af erhvervs- og finanspolitikken. Med henblik på lande, der permanent og igen og igen overtræder Stabilitets- og Vækstpagten, drejer det sig i første række om at skaffe sig en mulighed for at gribe ind og virkelig få indflydelse på deres krænkelser af Stabilitets- og Vækstpagten".

Den tyske regering mener, at eurolandene allerede inden for den gældende traktats rammer kan styre krisen med følgende redskaber:

1) Eurostaterne kan allerede nu forelægge Kommissionen deres finans- 
love, før de fremsættes i de nationale parlamenter. Det gør europagten mere troværdig.

2) Man har oprettet den midlertidige valutafond EFSF til støtte for kriseramte eurolande.

3) Man har vedtaget, at EFSF efter planen skal afløses af den Europæiske Stabilitetsmekanisme, EMS, i juni 2013.

4) IMF har allerede længe været inddraget i redningsaktionen.

5) Private kreditorer er også blevet inddraget.

6) Den Europæiske Centralbank har midlertidigt og undtagelsesvis opkøbt statsobligationer. Dette forhold vil blive afsluttet med etableringen af ESM.

Eurozonen ville utvivlsomt have oplevet mange kriser. Men den havde med sikkerhed undgået en livstruende krise, hvis medlemslandene havde overholdt de konvergenskriterier, de selv havde skrevet under på ved møntens indførelse. Blandt kriterierne kræves det, at inflationen skal holdes under 1,5 procent, det årlige budgetunderskud må ikke overstige 3 procent af BNP, og den samlede statsgæld må ikke overstige 60 procent af BNP.

\section{Uden straffemekanisme}

Ingen af disse krav er blevet taget særlig alvorligt. De to store økonomier Tyskland og Frankrig gik i årevis i spidsen med et budgetunderskud, der langt oversteg 3-procents- loftet. De to lande har optaget en samlet statsgæld på hver omkring 82 procent af deres BNP. Med andre eurolande står det langt værre til på alle fronter. Duksene er få.

Problemet er, at der ikke blev etableret en automatisk straffemekanisme, da møntunionen blev indført. Den ene hånd kunne vaske den anden. Derfor skal der fremover automatisk falde bøder, hvis konvergenskriterierne overskrides.

De tiltag, som Tyskland og Frankrig forestiller sig, og som Danmark som formandsland skal være med til at institutionalisere, har naturligvis størst interesse for eurolandene Tyskland, Frankrig, Italien, Spanien, Holland, Belgien, Luxemburg, Irland, Finland, Østrig og Portugal (alle med fra 1999) og de senere tilkomne: Grækenland (2001), Slovenien (2007), Cypern og Malta (2008), Slovakiet (2009) og Estland (2011). Men interessen deles af alle de andre, også Storbritannien.

De EU-lande, der står uden for euroen, har for de flestes vedkommende ligesom Danmark knyttet deres valutaer til eurokursen. Det samme har Schweiz, der ikke er medlem af EU og heller ikke har nogen planer om at blive det.

Danmark og Storbritannien er de to eneste EU-lande, der udtrykkeligt har undtaget sig selv fra kravet om at indføre euroen. De otte resterende EU-lande skal arbejde på at opfylde euroens konvergenskriterier. Den svenske regering har dog med- 
delt, at euroen ikke længere er et svensk perspektiv.

Polen havde EU-formandskabet i sidste halvdel af 2011. Et af dette formandskabs mål var at sikre vedvarende vækst i hele Europa med en 'Stabilitetsunion'. Det hedder i det danske oplæg, at "det er et helt overordnet vilkår for det danske formandskab, at Europa også i 2012 fortsat vil være på vej ud af den økonomiske og finansielle krise. Dette vil afspejle sig i den forventede dagsorden under det danske formandskab, hvor der bl.a. vil være fokus på at skabe vækst og sikre bedre økonomisk koordination mellem landene".

Ordene peger i retning af en forsigtig forståelse for de tysk-franske krav. Men samtidig understreger de lavmælt, at Danmark ligesom Polen kæmper for, at der ikke opstår et EU i to hastigheder. De ti lande, der ikke er med i eurozonen, vil ikke acceptere, at afgørende beslutninger bliver truffet blandt eurolandene, inden de kommer op i det samlede forum.

\section{Lissabon-traktaten}

Så vidt, så godt. Men det er naturligvis ikke gjort med det. EU kommer ikke uden om ændringer i Lissabontraktaten. I betragtning af at det tog næsten et tiår at bakse denne traktat igennem de parlamentariske beslutningsprocesser i medlemslandene, er det ikke et opmuntrende budskab.
Det første skridt til traktaten blev taget, da EU i 2001 nedsatte et konvent, der skulle formulere en ny traktat. Resultatet var et glimrende skridt fremad for den Europæiske Union. Alligevel blev traktaten forkastet i Frankrig og Holland i sommeren 2005 ved folkeafstemninger, der nok så meget handlede om andre temaer, fx den fjerne udsigt til et tyrkisk EU-medlemskab.

EU-landene gav sig herefter en såkaldt 'tænkepause', der kom til at vare i hele to år. Først i 2007 lykkedes det Angela Merkel at give traktatforhandlingerne et nyt mandat, hvori ordet 'forfatning' ikke forekom. Den 13. december 2007 blev det nye traktatforslag underskrevet af medlemslandene i Lissabon i Portugal, men allerede året efter væltede Irland læsset, da et vælgerflertal på 53 procent ved en folkeafstemning afviste det. Irland fik en række garantier, herunder, at det fortsat er ulovligt at få foretaget abort i Irland. Ved en anden afstemning i oktober 2009 sagde irerne så omsider ja til den reviderede traktat med 67,1 procents flertal. Senere samme år gav forfatningsdomstolen i Tjekkiet grønt lys for aftalen, og dermed var den aller allersidste hindring væk.

Lissabon-traktaten trådte herefter i kraft 1. december 2009.

Intet under, at Hermann Gröhe, generalsekretær i Merkels parti CDU, ikke vil kræve en totalrevision af traktaten: "Det ville belaste os med årelange forhandlinger. Vi har 
brug for målrettede forandringer. Vores mål skal være at være færdige inden for et år", sagde han i september 2011 til avisen Frankfurter Allgemeine Zeitung.

\section{EU's eksistenskrise}

Gröhes partiformand, Angela Merkel, udtrykte det sådan i Forbundsdagen den 26. oktober:

"Jeg er mig helt og holdent bevidst: En traktatændring rummer altid risici. Det er en besværlig vej. Alle 27 medlemsstater må give deres tilslutning. Dog er det den nødvendigste og bedste måde at hindre en opsplittelse af EU i euro- og ikkeeuro-stater. Lykkes det os ikke, så er det en nødvendighed, at eurostaterne aftaler bindende traktater med hinanden. Det ønsker jeg ikke. Det ville jeg ikke finde fornuftigt, da der endnu er mange lande, der vil tiltræde euroen. Derfor må man være beredt til at gå denne vej”.

Hun tilføjede: "Da vi står i en eksistenskrise i Europa, spørger jeg: Hvor står det egentlig skrevet, at en traktatændring altid skal vare ti år? Hvem ude omkring vil tiltro os handlekraft, hvis vi træder til side og siger: 'Efter Lissabon-traktaten bør der aldrig igen ske ændringer?' Hele verden ændrer sig, altså må også Europa være forandringsberedt".

De ændringer, den tyske regering forestiller sig, ser således ud:

1) Formanden for Europa-Kommis- sionen skal vælges særskilt af EU's vælgere ved næste Europa-Parlamentsvalg.

2) Beslutningsstrukturen i EU skal ligne et tokammersystem: Et direkte valgt Europa-Parlament og Ministerrådet som 'senat' for medlemslandene. Begge kamre skal ved siden af Kommissionen have initiativret.

3) Mellemstatslige aftaler skal integreres i traktaten (som det er sket med Schengen-aftalen).

4) Europa-Parlamentet skal i højere grad sammensættes efter befolkningstal i medlemslandene.

Særligt for det valutariske samarbejde skal traktaten ændres efter følgende model:

1) Valutaunionen ændres til en Stabilitetsunion. Der tales om 'fuldendelsen af Økonomi- og Valutaunionen'.

2) Europagten skal forsynes med automatiske straffemekanismer, og europagten skal optages i EU-traktaten.

3) Der skal indføres et loft for finanslovsunderskud efter tysk mønster.

4) Den Europæiske Domstol skal kunne dømme i spørgsmål om krænkelser af Stabilitets- og Valutapagten.

5) Der skal etableres en ordning $i$ flere trin, der kan hjælpe lande med at bringe deres finansunderskud i orden, eventuelt med hjælp fra EUkommissionen.

6) Fra 2013 skal EMS være en europæisk valutafond (som IMF). 
7) Der skal indføres regler for planmæssig gældsafvikling.

8) Kommissionen skal have en ny kommissær med ansvar for besparelser med ret til at gribe ind.

9) Desuden skal et land kun kunne optages i eurozonen, hvis man accepterer de nye regler.

Der er ingen grund til at tro, at alle disse traktatændringer vil blive formuleret, for slet ikke at tale om vedtaget under det danske formandskab, selv om den tyske frist er et år. Men Helle Thorning-Schmidt og hendes embedsmænd må gøde jorden for mange af disse idéer, der i høj grad er kontroversielle i Danmark. Hver gang hun kan melde om sejr i Bruxelles, vil det automatisk fremstå som et nederlag i København, i alt fald i EU-kritiske kredse. Det bliver ikke mindst spændende at se, hvordan den danske udenrigsminister Villy Søvndal, hvis parti SF holder fast på vores 3,5 undtagelser, som var de kronjuveler, vil optræde i dette hajfyldte farvand.

Og kan de vedtages, uden at Danmark igen skal kastes ud i en opslidende diskussion om folkeafstemninger?

\section{Weimar-trekanten}

Et fjerde område, hvor Danmark kommer ind på tværs, er forsvarssamarbejdet.

Også det blev vi undtaget fra, da vi underskrev Maastricht-traktaten i 1993. Det skal intensiveres, mener
Tyskland, Frankrig og Polen. Men det er næppe den danske holdning. Tyskland har tilkendegivet over for Danmark, at Berlin er interesseret i, at vi under vores formandskab fortsætter det arbejde, som Polen, det tidligere formandsland, har gjort $\mathrm{i}$ sidste halvdel af 2011. Det drejer sig om at vække EU's Fælles Sikkerhedsog Forsvarspolitik, CSDP, til live. CSDP er en del af Unionens fælles udenrigs- og sikkerhedspolitik, og den fik dette navn i Lissabon-traktaten i 2009, den traktat, der nu skal omredigeres, hvis det står til Tyskland og Frankrig.

Ifølge vedtægterne for CSDP skal den fælles sikkerheds- og forsvarspolitik med tiden føre til et fælles europæisk forsvar, når det Europæiske Råd, altså stats- og regeringscheferne i EU, vil det så. Det hedder også i formålsparagraffen, at CSDP ikke må konflikte med de allianceforpligtelser, som de fleste EU-lande har ifølge deres medlemskab af NATO. EU's mål skal heller ikke adskille sig fra NATOs. Til gengæld giver det EU-lande, der ikke er med i NATO, en øget sikkerhedsgaranti.

Tyskland, Frankrig og Polen vedtog i april 2010 at sætte skub i dette hensygnende foretagende. De oprettede noget, de kaldte 'Weimartrekanten' efter den tyske by, hvori aftalen blev formuleret. De ønsker, at EU opretter et egentligt militært hovedkvarter, i fagsproget forkortet HQ. Det skal give EU en permanent civil-militær planlægnings- og kom- 
mandostruktur og det vil, ifølge de tre landes argumentation, betyde en mere effektiv brug af ressourcerne.

"Hvis EU fortsat vil engagere sig i krisestyring og udføre komplekse civil-militære opgaver, kan det kun ske med de dertil egnede indre EUstrukturer", hedder det i Weimar-trekantens argumentation.

Lignende initiativer er tidligere mislykkedes af politiske grunde. EU har strukturerne til det, men savner et permanent HQ. Adskillige lande, herunder ikke mindst Storbritannien, har vedvarende afvist at skabe et sådant EU HQ af frygt for, at det kan skade NATO og det transatlantiske forhold.

Analytikere peger på, at kravet om et HQ også rejser det politiske spørgsmål om, hvor stor EU's autonomi skal være på et nøgleområde for den nationale suverænitet i sikkerheds- og forsvarspolitikken. Her er tale om en vanskelig balancegang mellem medlemsstaternes suverænitet og unionens. Her er der stor uenighed i EU.

Frankrig, der i mange år slet ikke var medlem af NATO, står for det radikale standpunkt, Storbritannien, USA's europæiske trædesten, for det stik modsatte, og Tyskland forsøger sig som mægler med et kompromis lidt midt imellem. I 2010 blev duoen så til en trio, da Polen sluttede sig til projektet. Polen kalder et EU HQ en styrkelse af de transatlantiske bånd.

Vurderingen er, at initiativet har meget ringe chancer for at nyde fremme. Alligevel presser Guido Westerwelle, den tyske udenrigsminister, på for at holde debatten i gang under det danske formandskab.

Hvordan Villy Søvndal, hans danske modpart, eller 'homolog', som det hedder på fransk, skal fremme denne sag, står ikke helt klart. CSDP står allerede for civile missioner i Kosova og Afghanistan, og her er Danmark en af de store bidragydere.

\section{Euratom}

På den danske ønskeliste til formandskabet står emner som klima, energi og miljø. Det er også emner, der i høj grad har Tysklands opmærksomhed. I juni 2001 besluttede den tyske regering officielt, at landet udfaser sin atomkraft omkring 2021-22. Regeringen havde ellers til glæde for ikke mindst atomkraftværkernes ejere i oktober 2010 forlænget kerneenergiens fremtid i Tyskland med 20 til 30 år i forhold til den aftale om udfasning, som den daværende socialdemokratisk-grønne regering traf med atomindustrien i 2001. Den aftale havde nøjagtig samme slutdato som den, der nu gælder.

Det betyder, at Tyskland skal omlægge hele sin energiforsyningsstrategi med særlig vægt på, at vedvarende energikilder gradvist skal træde i stedet for fossile. Dette projekt, der kan antage gigantiske dimensioner, har utvivlsomt den nye danske rege- 
rings største interesse. Men i netop spørgsmålet om kerneenergi rejser der sig et særligt problem, der kan blive et varmt emne under det danske formandskab: Fremtiden for det Europæiske Atomfællesskab, også kaldet Euratom, der blev grundlagt i 1957. Samarbejdet er en del af Lissabon-traktaten. Dets formål er at fremme den hurtige udvikling af kerneindustri i medlemsstaterne og at sikre gensidig kontrol ved at 'fællesgøre' atomteknikken i medlemslandene.

Alle 27 EU-lande er medlem af Euratom, men 12 EU-lande har ikke atomkraft. Det gælder jo fx Danmark. Alene i 2011 tog to EU-lande, Tyskland og Belgien, definitivt afsked med atomkraften, mens Italien ved en folkeafstemning vedtog aldrig at indføre den. Spanien har også besluttet at stige ud, og Østrig har fået forankret i sin forfatning, at landet aldrig vil indføre atomkraft. Uden for EU vedtog Schweiz i 2011 at udfase sin atomkraft.

Der er altså tale om en energiform, der er på vej ud af billedet $\mathrm{i}$ Europa, selv om store EU-lande som Frankrig og Storbritannien stadig sværger til den - Frankrig har endda planer om at lægge nye atomkraftværker på havets bund. Det er et spørgsmål, om dette dristige projekt mindsker faren for atomkatastrofer som den, Japan oplevede i marts
2011, da dets østkyst blev overskyllet af en flodbølge.

Allerede i 2007 erklærede fem medlemsstater, Tyskland, Irland, Østrig, Sverige og Ungarn, at Euratom-aftalen er forældet og skal omarbejdes på en regeringskonference. Sverige har siden foreløbig ubegrænset forlænget sine atomkraftværkers levetid og lægger måske nu mindre vægt på kravet. Det danske Folketing krævede i enighed i 2004 Euratom ændret, så vi ikke længere med millioner af skattekroner støtter drift af gamle værker og opførelse af nye.

Her er tale om et indsatsområde, hvor danske og tyske interesser forenes. De store beløb, der går til opretholdelse af atomkraft i Europa, kan efter manges mening bruges bedre i den fremtidige energistrategi, som Tyskland har lagt.

Frankrig og Storbritannien, der nyder særdeles godt af de mange atomtilskud bl.a. fra Danmark, er hårde modstandere af tanken. Men Danmark og Tyskland kunne med fordel bruge det næste halvår til at bryde isen op, når retningen væk fra kerneenergi nu entydigt er lagt. Tyskland betalte i 2011117 millioner euro til Euratom.

Peter Wivel er Politikens korrespondent $i$ Berlin. 